\title{
Torture in the Kashmir Valley and Custodial Deaths in India
}

\author{
Inamul Haq*
}

Dear Editor,

I would like to draw your readers' attention to the fact that custodial violence and death is a dark reality in India, where the poor, the deprived classes, women and political activists are the worst victims of police brutality in India (Prakash and Chaudhary, 2015). It has even been reported that women, religious minorities, the poor and vulnerable sections of society are specifically targeted (National Project on Preventing Torture in India, 2008). Since the unrest that started with the insurgency in the Kashmir Valley in the 1990's, the Indian state has systematically used force and coercion with a view to making citizens compliant in the region. Normal Kashmiri people are arrested by police and security forces in order to identify suspected militants. Arrest can occur on the basis of suspicion rather than evidence leading to abuse by police. Thousands have disappeared, not only in Kashmir, but also in Jammu. In 2011 for example, the State Human Rights Commission (SHRC) of Jammu and Kashmir found 2730 bodies dumped in unmarked graves in 38 sites in North Kashmir. Among them, 574 were identified as the bodies of local Kashmiris

^) PhD candidate under the supervision of Dr Beryl Anand, Assistant Professor, Centre for Gandhian Thought and Peace Studies, Central University of Gujarat
(Human Rights Watch, 2012). Police, security forces and intelligence agencies use torture in the form of assault, physical abuse, custodial deaths, rape, threats, psychological humiliation and deprivation of food, water, sleep and medical attention. Torture in custody is now considered an inevitable part of any police investigation as it is widely practised throughout India (Seth, 2010). Authorities consider torture to be an interrogational tool for investigation and perceive that there is nothing wrong in punishing a victim in custody.

The rate of deaths in custody is also high (Lokaneeta, 2011). The Indian National Human Rights Commission (NHRC) records that from 2001-2010, 14,236 individuals died in custody $(1,504$ in police custody and 12,732 in judicial custody), which is an average of 4.3 deaths per day. Most of the deaths occurring are the direct result of torture in custody. All cases of death in police and prison custody are not documented because the National Human Rights Commission does not have jurisdiction over armed forces (section 19, Human Rights Protection Act (NHRC, 2011)). These deaths occur either due to negligence by authorities with respect to hygiene levels of food and deprivation of medical assistance, or by unlawful, prolonged detention and torture. The Asian Centre for Human Rights (2011) has consistently underlined that about $99.99 \%$ of deaths in police custody can be ascribed to torture and generally occur within 
forty-eight hours of the victims being taken into custody.

Torture and other human rights abuses like arbitrary detention and disappearances are particularly common in Jammu and Kashmir and North-Eastern states and extra-judicial killings and death in custody are said to be increasing in the Kashmir Valley (Haneef, 2015). The Indian Penal Code which stipulates that arrestees must be brought before a magistrate within 24 hours is not upheld in the region and security forces have virtual immunity from prosecution.

Yet, it is a paradox that torture continues to exist in India (Seth, 2010). India is a liberal democracy with clear national constitutional and statutory provisions against torture that are purportedly being developed and monitored by a strong and independent judiciary. The Supreme Court of India condemns torture and has outlined best practices for police and other state actors. However, state legislatures have not responded by codifying these national provisions and practices into law. This inaction has led to torture and ill-treatment not being challenged and a culture of impunity (NPTTI, 2008). India does not allow any international organizations like Amnesty International and Human Rights Watch or domestic human rights organizations, like the National Human Rights Commission, to document cases of torture and other abuses in the Jammu and Kashmir and northeastern states like Manipur (Amnesty International, 2016/17). In Kashmir valley, the laws, like the Armed Forces Special Power Act 1990, have not only suspended the powers of the judiciary and accountability within the everyday legal system, but also provide extensive legal protection to the armed forces (Duschinski, 2010). In the Kashmir Valley, torture is practiced as a means of extracting information or a confession, or for punishing persons who are believed to be supporters of militants (OFMI, 2012). Methods used are brutal which physically and psychologically impair the victims and can mean they face health problems throughout life. Many victims become militant (Kashmir Coalition Civil Society, 2009).

The concept of modern policing is still a mirage in India, where police are expected to function as a tool for social control rather than to serve the society. The increasing incidence of torture and deaths in custody has assumed such alarming proportions that it is undermining the rule of law and the administration of criminal justice system.

\section{References}

Amnesty International. (2016/17). Amnesty International Annual Report. London: Amnesty International Ltd

Asian Centre for Human Rights. (2011). Torture in India 2011. New Delhi: Asian Centre for Human Rights.

Duschinski, H. (2010). Reproducing regimes of impunity: Fake encounters and the informalization of everyday violence in Kashmir valley. Cultural Studies, 24(1), 110-132. https://doi. org/10.1080/09502380903221117

Haneef, K. M. (2015). Impunity to Military Personal in Kashmir Valley, a Heart Touching Debate Since 1989. International Research fournal of Social Sciences, 4(7), 54-58. World Report. (2012). USA: Human Rights Watch.

Organization For Minorities in India. (2011). Torture commons by police officers in India. India: Organization For Minorities in India.

Lokaneeta, J. (2011). Transnational torture: law, violence and state power in the United States and India. New York: New York University Press.

National Project on Preventing Torture in India. (2008). Torture and Impunity in India. Tamil Naidu: Peoples Watch.

Jammu and Kashmir Coalition Civil Society. (n.d.) Peace and Processes of Violence: An observation on situation in fammu and Kashmir from 2002 to 2009. Srinagar: Jammu and Kashmir Coalition Civil Society.

Prakash, A. \& Chaudhary, A. (2015). Custodial torture: a naked violation of human rights. International Fournal of Legal E Social Studies. 2(2), 42-58.

Seth, R. (2010). Custodial torture and its remedies. Retrieved from http:/www.legalservicesindia.com/ article/article/custodial-torture-297-1.html. 